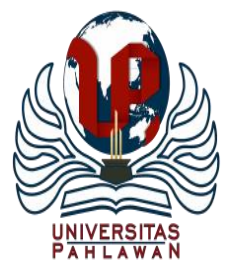

Edukatif : Jurnal Ilmu Pendidikan Volume 3 Nomor 4 Tahun 2021 Halm 2185 - 2191

EDUKATIF: JURNAL ILMU PENDIDIKAN

Research \& Learning in Education

https://edukatif.org/index.php/edukatif/index

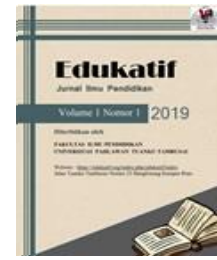

\title{
Pengaruh Konseptual Achievement Emotion dan Lingkungan Belajar Peserta Didik terhadap Achievement Goal
}

\author{
Harry Theozard Fikri1 ${ }^{1 凶}$, Billy Hendrik ${ }^{2}$, Mardhiah Masril ${ }^{3}$ \\ Universitas Putra Indonesia, YPTK Padang, Indonesia ${ }^{1,2,3}$

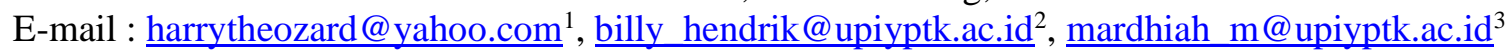

\begin{abstract}
Abstrak
Tujuan penelitian ini untuk menguji pengaruh pemahaman achievement emotion dan lingkungan belajar terhadap achievement goal peserta didik pada SMK PGRI Padang. Achievement goal diartikan sebagai motivasi dan dorongan pribadi yang menuntun seseorang untuk pencapaian tujuan tertentu, dan berpedoman pada kriteria yang digunakan dalam menilai keefektifan dalam mencapai tujuan. Subjek penelitian adalah kelas XI sebanyak 136 siswa. Instrumen pengumpul data dengan angket skala konseptual tentang achievement emotion (25 pernyataan), skala lingkungan belajar (20 pernyataan), dan skala achievement goal (15 pernyataan). Analisis data dengan uji regresi berganda diolah dengan SPSS Statistics 17. Temuan ini mengungkapkan bahwa pemahaman siswa terhadap achievement emotion dan lingkungan belajar berdampak besar pada tujuan prestasi (achievement goal) mereka, karena achievement goal adalah faktor-faktor yang dapat berpengaruh pada motivasi serta keberhasilan siswa untuk belajar dan meraih prestasi, penelitian ini dimaksudkan untuk memberikan informasi tentang nilai tujuan prestasi.
\end{abstract}

Kata Kunci: achievement emotion, lingkungan belajar, achievement goal.

\begin{abstract}
This study aimed to examine the effect of understanding achievement emotion and the learning environment on the achievement goals of students at SMK PGRI Padang. Achievement goals are defined as personal motivation and encouragement that guide a person to achieve specific goals and are guided by the criteria used in assessing effectiveness in achieving goals. The research subjects were class XI totaling 136 students. The data collection instrument used a conceptual scale questionnaire about achievement emotion (25 statements), learning environment scale (20 statements), and achievement goal scale (15 statements). Data analysis using multiple regression test was processed with SPSS Statistics 17. These findings reveal that students 'understanding of achievement emotion and the learning environment has a significant impact on their achievement goals because achievement goals can affect students' motivation and success for learning and achieving. This study is intended to provide information about the value of achievement goals.
\end{abstract}

Keywords: achievement emotion, understanding of the learning environment, achievement goal.

Copyright (c) 2021 Harry Theozard Fikri, Billy Hendrik, Mardhiah Masril

$\triangle$ Corresponding author

Email : harrytheozard@yahoo.com $\quad$ ISSN 2656-8063 (Media Cetak)

DOI : https://doi.org/10.31004/edukatif.v3i4.1155 ISSN 2656-8071 (Media Online) 


\section{PENDAHULUAN}

Di abad-21 ini, perkembangan teknologi dan komunikasi berkontribusi pada munculnya masyarakat global di mana orang-orang cerdas dengan berbagai keterampilan dan pengetahuan terbentuk, sehingga pada pasar global setiap orang harus lebih kompetitif. Perlu kesadaran akan pentingnya skill, pengetahuan, dan kemampuan intelektual untuk menghadapi tantangan global. Pendidikan sebagai proses pembelajaran sangatlah penting dalam pengembangan skill dan pengetahuan yang kelak dapat diterapkan di dunia yang kompetitif (Dakhi et al., 2020). Di era persaingan global ini, generasi muda harus menjawab tantangan keterampilan dan persaingan global yang semakin meningkat. Generasi muda harus memiliki kemauan dan dedikasi untuk maju dalam pekerjaan nyata. Oleh karena itu, generasi muda diharapkan dapat menggali dan mengembangkan keterampilan di berbagai bidang. Keterampilan dan pengetahuan pribadi juga membantu dalam merencanakan masa depan, terutama saat merencanakan karier (Wardani et al., 2018). Keterampilan ini meliputi: keterampilan belajar; pengembangan ide serta pengembangan sistem pemikiran untuk perencanaan, pengelolaan dan evaluasi inovasi seperti pemikiran kreatif dan rencana karir masa depan (Wahyudi et al., 2021).

Generasi muda, terutama Gen Z yang lahir tahun 2000-an. Generasi ini hidup di era digital, bekerja di dunia teknologi. Saat kita memasuki era digital, orang memiliki kebebasan berekspresi dan akses ke semua informasi yang mereka butuhkan. Generasi ini tahu pentingnya prestasi akademik dan non-akademik. Mereka tidak hanya berlomba untuk membuktikan kemampuannya, tetapi juga menunjukkan ketulusan dalam mengejar prestasinya (Putri \& Supriansyah, 2021). Kompetisi mencerminkan prestasi mereka, dimana kompetisi merupakan bukti kualitas dan kreativitas mereka. Jika siswa memiliki motivasi belajar yang rendah, artinya dia memiliki persepsi kompetensi yang rendah. Individu dengan persepsi kompetensi yang rendah akan memiliki usahayang kurang untuk mencapai tujuan tertentu. Seseorang dengan persepsi kompetensi rendah cenderung lemah secara emosional dan memiliki respon motivasi yang tidak tepat. Individu yang meng-adopsi pendekatan pencapaian tujuan (achievement goal), yaitu tujuan kinerja tinggi, berusaha maksimal untuk mencapai prestasi yang maksimal juga (Putra \& Soetikno, 2018; Saraswati, 2019).

Prestasi bergantung pada faktor eksternal dan internal. Status sosial ekonomi, lembaga pendidikan, dukungan orang tua, guru dan statistik lainnya merupakan pengaruh oleh faktor eksternal. Sedangkan faktor internal yakni faktor psikologis, motivasi, dan tanggung jawab yang mendorong seseorang untuk menjadi lebih baik. Penelitian menunjukkan bahwa pencapaian tujuan (achievement goal) mempengaruhi prestasi dan kinerja siswa dalam mencapai tujuan mereka. Achievement goal memiliki pengaruh yang berbeda terhadap prestasi setiap sekolah melalui perubahan kualitas proses kognitif dalam bentuk peraturan yang dinilai (Damayanti et al., 2017; Hadi \& Netrawati, 2021). Sikap cognitive self-regulation untuk analisis tugas kognitif diberikan untuk mempelajari kegiatan sekolah, merencanakan dan memobilisasi sumber daya untuk memenuhi layanan penuh dan menyelesaikan tugas, oleh karena itu kualitas waktu, proses kognitif, dan strategi kognitif yang sesuai dalam pengontrolan kualitas prestasi dipengaruhi achievement goal. Achievement goal adalah variabel utama yang bisa dipelajari, diprediksi dan permorma belajar siswa. Motivasi siswa yang berjuang untuk berprestasi (status berprestasi), misalnya saat berada di kelas, dapat digambarkan sebagai tujuan berprestasi (achievement goal).

Berbagai alasan mengapa siswa mengupayakan pencapaian yang diwakili oleh komponen tujuan pencapaian, seperti penguasaan tujuan dan tujuan kinerja. Penelitian mengungkapkan bahwa achievement goal berpengaruh terhadap motivasi serta performa siswa dalam meraih prestasi mereka (Damayanti et al., 2017; Kohoulat et al., 2016). Achievement goal mempengaruhi prestasi disekolah secara berbeda-beda pada tiap individu melalui variasi dari kualitas proses kognitif yang berupa regulasi diri masing-masing individu tersebut. 
Siswa mencapai prestasi hanya karena tuntutan dari lingkungan sekitar atau tidak ingin terlihat gagal. Uraian tersebut berdasarkan pengertian orientasi tujuan performa yang menggambarkan fokus seseorang dalam menunjukkan kompetensi dan kemampuan dirinya, agar mendapat penilaian positif dari orang lain serta lebih mementingkan sebuah hasil dibandingkan proses. Selain untuk menunjukkan kompetensi dan kemampuannya, siswa yang berorientasikan tujuan performa juga memiliki keinginan untuk menghindari pembuktian akan kurangnya kemampuannya. Seseorang dengan orientasi tujuan performa lebih peduli dengan tampil secara maksimal. Siswa dengan orientasi tujuan performa dianggap sukses ketika mereka berhasil menunjukkan kompetisinya didepan teman-teman dan guru (Dluha \& Solicha, 2019). Pernyataan ini sesuai dengan penelitian (Nurcahyanti \& Setyawan, 2014) yang menyatakan bahwa siswa dengan orientasi tujuan performa cenderung lebih kuat untuk menunjukkan dirinya di depan umum, dibandingkan dengan siswa pada umumnya pun menyatakan bahwa siswa dengan orientasi tujuan performa cenderung lebih tertutup terhadap tantangan karena memandangnya sebagai ancaman terhadap peringkatnya (Muna, 2017).

Pencapaian tujuan (achievement goal) ialah faktor penting dalam meningkatkan prestasi. Faktor-faktor yang mempengaruhi tujuan termasuk tujuan yang berbeda pada setiap individu, ekspektasi kesuksesan individu, ketakutan akan kegagalan, persepsi mereka tentang lingkungan belajar mereka, dan achievement emotion (Pekrun, 2014). Pencapaian prestasi selalu disertai dengan achievement emotion diantaranya perasaan senang pada saat belajar, kebanggaan, rasa cemas,amarah, putus asa, rasa malu, dan kebosanan, biasa terjadi dalam membangun prestasi. Emotion ini penting karena mempengaruhi motivasi siswa, baik dari segi pembelajaran, prestasi akademik, identifikasi perkembangan, dan kesehatan (Kohoulat et al., 2016). Ukuran achievement goal (pencapaian tujuan), yaitu tujuan penguasaan dikaitkan dengan emosi aktivitas, seperti kesenangan, kebosanan, dan kemarahan; Sasaran kinerja dikaitkan dengan emosi positif seperti harapan dan kebanggaan (Artino \& Jones, 2012).

Faktor lain yang mempengaruhi achievement goal adalah persepsi siswa terhadap lingkungan belajar mereka. Penelitian menunjukkan bahwa siswa menyesuaikan pendekatan mereka untuk belajar dengan menyesuaikannya dengan persepsi mereka tentang lingkungan belajar. Menurut penelitian oleh Radovan, \& Makovec (2016), persepsi siswa tentang lingkungan belajar memengaruhi tujuan (achievement goal) mereka, sasaran sukses memengaruhi tingkat kinerja siswa dan motivasi penting untuk belajar. Penelitian Anggraini dkk. (2017) Menunjukkan jika lingkungan belajar memiliki tingkat kontribusi yang signifikan kepada hasil belajar karena hakikatnya belajar merupakan proses individu berinteraksi dengan lingkungannya sehingga lingkungan sangat penting untuk menaikkan hasil belajar. Hasil penelitian selanjutnya ditemukan bahwa hasil belajar dipengaruhi oleh lingkungan belajar secara positif. Lingkungan belajar dengan kondisi nyaman serta kondusif merupakan tulang punggung dan pendorong proses pembelajaran berjalan dengan baik dan lancar. Apabila lingkungan belajar baik maka akan baik pula hasil belajarnya (Pratama \& Ghofur, 2021).

Berdasarkan pembahasan dan kajian di atas, maka penulis berkeinginan untuk melakukan penelitian untuk melihat pengaruh dari variabel lingkungan belajar dan achievement emotion terhadap achievement goal. Tujuan penelitian ini untuk menguji pengaruh pemahaman achievement emotion dan lingkungan belajar terhadap achievement goal peserta didik pada SMK PGRI Padang.

\section{METODE PENELITIAN}

Penelitian ini menggunakan pendekatan kuantitatif. Penelitian ini adalah korelasional, dengan teknik pengumpulan data survei. Kuesioner untuk penelitian ini menggunakan skala likert. Ini merupakan ukuran sikap yang meliputi dua jenis pernyataan yaitu pernyataan tentang subjek sikap yang terdiri pernyataan positif dan negatif. Dalam penelitian ini, variabel bebas (X) ialah pemahaman lingkungan belajar (X1) dan achievement emotion (X2). Dalam penelitian ini kesadaran lingkungan (X1) merupakan komposisi, pemaknaan dan interpretasi siswa terhadap aspek psikososial yang mempengaruhi lingkungan belajar, iklim 
belajar dan suasana serta suasana pembelajaran. Instrumen untuk mengukur persepsi lingkungan belajar terdiri dari 20 pernyataan dengan reliabilitas baik $(\alpha=0,912)$.

Terdapat empat pilihan jawaban yang merepresentasikan pernyataan pada skala persepsi lingkungan belajar, yakni: sangat tiidak setuju (STS), tidk ksetuju (TS), setuju (S) dan sangat setuju (SS). Ini. Variabel achievement emotion ialah emosi yang berhubungan dengan kegiatan berprestasi dalam penelitian ini. Alat ukur achievement emotion disusun penulis berdasarkan teori Pekrun Value Control (2011) yang terdiri dari 25 item yang reliabel $(\alpha=0,781)$. Terdapat terdiri dari empat pilihan yang merepresentasikan pernyataan pada skala achievement emotion: sangat tidak setuju (STS), tidaki setuju (TS), setuju (S), dan sangat setuju (SS).

Variabel terikat (Y) yakni achevement goal, yang didefinisikan sebagai motif dan dorongan seseorang untuk mencapai tujuan yang telah ditetapkan sebelumnya, yang didasarkan pada standart dalam evaluasi performa. Alat pengukuran achievement goal adalah mengadaptasi Achievement Goal Questionnaire Revised (AGQR) yang terdiri dari 15 pernyataan reliabel $(\alpha=0.820)$, yang dikembangkan oleh Xiao, et all (2016). Pada skala achievement goal terdapat empat pilihan respon yang menunjukkan pernyataan yang sesuai dengan situasi subjek. Populasi penelitian ini adalah siswa SMK PGRI Padang. Jumlah siswa di SMK PGRI Padang adalah 374orang sampel penelitian adalah kelas XI berjumlah 136 orang.

\section{HASIL DAN PEMBAHASAN PENELITIAN}

Sebelum melakukan uji regresi berganda, penulis melakukan beberapa uji prasyarat, antara lain uji normalitas, uji linieritas, uji homogenitas, dan uji multikolinieritas. Uji Kolmogorov-Smirnov digunakan untuk uji normalitas. Dengan teknik ini, data dianggap normal jika nilai absolut (D) dan Kolmogorov-Smirnov (Z) lebih besar dari 0,05 (Priyatno, 2010). Nilai absolut (D) ketiga variabel lebih besar dari 0,05. Nilai z dari ketiga variabel juga lebih besar dari 0,05 . Nilai $\mathrm{Z}$ variabel achievement goal 1,38, pemahaman lingkungan belajar 0,76, dan achievement emotion 1,52. Berdasarkan ini, tiga variabel berdistribusi normal.

Uji linieritas menunjukkan bahwa terdapat hubungan linier antara variabel achievement emotion dengan variabel kinerja tujuan dan terdapat hubungan linier antara persepsi lingkungan belajar dengan variabel achievement goal (Sig. 0,005). Hasil uji kovarians diagram pencar menampilkan diagram sampel dengan nilai 0 beserta varian skor yang tersisa, dan skor prediksi itu sendiri tidak menunjukkan kasus varian yang tidak rata. Menurut uji multikolinearitas, toleransi > 0,10 (atau 0,973) dan nilai VIF < 10 (atau 1,014). Hal ini berarti bahwa asumsi multikolinieritas terpenuhi.

Uji regresi berganda diperoleh nilai F sebesar 13,784 pada tingkat kepercayaan 5\% nilainya lebih besar dari 4, sehingga dapat disimpulkan bahwa semua variabel independen berpengaruh pada variabel dependen secara simultan. Variabel nilai selisih signifikan mewakili nilai 0,000 jika nilainya kurang dari 0,05 . Artinya pemahaman lingkungan belajar dan kinerja emosional berpengaruh signifikan terhadap pencapaian tujuan siswa SMK PGRI Padang. Koefisien determinasi menunjukkan achievement goal (Y) dipengaruh persepsi lingkungan belajar (X1) serta achievement emotion (X2) sebesar 13,4\% dan sisanya 86,6\% dipengaruhi oleh variabel lain yang tidak diukur dalam penelitian ini.

Berdasarkan rangkaian analisis bahwa terdapat pengaruh persepsi lingkungan belajar serta achievement emotion terhadap pencapaian tujuan (achievement goal) siswa. Penelitian ini menyajikan hasil yang sejalan dengan penelitian sebelumnya yakni adanya korelasi positif antara lingkungan belajar dan persepsi siswa terhadap pencapaian tujuan. Artinya jika pemahamaan siswa terhadap lingkungan belajar meningkat maka tujuan siswa juga akan meningkat. Konseptual siswa terhadap lingkungan belajar menentukan seberapa efektif pembelajaran dan seberapa banyak pengetahuan yang mereka peroleh sebagai hasil belajar.

Bagaimana siswa mempersepsikan, memahami, atau menjelaskan lingkungan belajar dipengaruhi oleh persepsi mereka sendiri tentang pembelajaran, penerapan dan persepsi lingkungan belajar. Persepsi siswa terhadap lingkungan belajar juga dipengaruhi oleh self-efficacy akademik, dimana konstruksi persepsi 
2189 Pengaruh Konseptual Achievement Emotion dan Lingkungan Belajar Peserta Didik terhadap Achievement Goal - Harry Theozard Fikri, Billy Hendrik, Mardhiah Masril

DOI: https://doi.org/10.31004/edukatif.v3i4.1155

merupakan aspek dari lingkungan belajar. Efikasi diri akademik dikaitkan dengan keyakinan pada kemampuan untuk berhasil dalam situasi tertentu dalam situasi tertentu.

Achievement goal adalah salah satu konstruksi terpenting yang terkait dengan pencapaian tujuan karena tidak hanya menunjukkan motivasi untuk keunggulan, tetapi juga mengacu pada kinerja yang merupakan penilaian tentang bagaimana melakukan pekerjaan secara efektif dalam mencapai tujuan lingkungan belajar dan rasa pencapaian adalah dua faktor yang secara unik mempengaruhi dan berkontribusi terhadap pencapaian tujuan (achievement goal) siswa di SMK PGRI Padang. Berdasarkan hasil penelitian bahwa masih terdapat siswa dengan level tujuan (achievement goal) yang relatif rendah atau sangat rendah, baik secara fisik, intelektual, dan sosial emosional, serta indikator perkembangannya. Berlandaskan hasil penelitian ini, konseptual achievement emotion dan lingkungan belajar secara efektif berkontribusi sebesar $14,5 \%$ terhadap pencapaian tujuan (achievement goal), sehingga penting untuk menganalisis $85,5 \%$ faktor lain yang dianggap sebagai prediktor pencapaian tujuan (achievement goal) siswa.

Penelitian ini sejalan penelitian Daryanti (2018), Kartika (2021) dan Widyaningtyas et al., (2013) yang menemukan pengaruh positif serta signifikan dari lingkungan belajar kepada hasil belajar. Lingkungan belajar yang mendukung seluruh kegiatan belajar siswa akan memberikan suasana yang nyaman dan dorongan bagi siswa untuk terus memacu prestasi belajarnya. Lingkungan yang baik perlu diusahakan agar dapat memberi pengaruh yang positif terhadap anak atau siswa sehingga dapat belajar dengan sebaik-baiknya. Juga selaras dengan hasil penelitian Fadilah et al., (2018) Kusumastuti \& Mastuti, (2018) bahwa lingkungan belajar dan achievement emotion memberikan sumbangan efektif positif terhadap achievement goal.

\section{KESIMPULAN}

Melalui serangkaian proses dan pengujian, diketahui bahwa konseptual achievement emotion dan lingkungan belajar berpengaruh terhadap pencapaian tujuan (achievement goal) siswa. Persepsi tentang achievement emotion dan lingkungan belajar secara efektif dipengaruhi oleh 13,4\%, sedangkan 86,6\% faktor lain yang tidak diteliti dalam penelitian ini yang dianggap prediktif/prediktor oleh siswa untuk mencapai tujuan (achievement goal). Penelitian ini menjadi acuan untuk menciptakan lingkungan belajar yang nyaman dan positif sehingga siswa dapat memandang lingkungan belajar secara positif ketika kesadaran lingkungan belajar dicapai melalui pendekatan yang berorientasi achievement goal. Penelitian ini diharapkan bisa bermanfaat dalam pemrolehan informasi tentang bagaimana peran lingkungan belajar persepsi dan perasaan berprestasi dapat mempengaruhi tujuan mereka dalam berprestasi, dimana prestasi dimotivasi dan prestasi dicapai. Oleh karena itu, perlu dipertimbangkan faktor-faktor apa saja yang akan mempengaruhi pencapaian tujuan (achievement goal), dan diharap teori masing-masing variabel lebih dipahami dan menjadi alat ukur yang lebih baik.

\section{DAFTAR PUSTAKA}

Artino, A. R., \& Jones, K. D. (2012). Exploring The Complex Relations Between Achievement Emotions And Self-Regulated Learning Behaviors In Online Learning. Internet And Higher Education, 15(3), 170-175. Https://Doi.Org/10.1016/J.Iheduc.2012.01.006

Dakhi, O., Jama, J., Irfan, D., Ambiyar, \& Ishak. (2020). Blended Learning: A 21st Century Learning Model At College. International Journal Of Multi Science, 1(7), 17-23.

Damayanti, K. A. Y. U., Ainy, N. U. R., \& Nawangsari, F. (2017). Jurnal Psikologi Pendidikan Dan Perkembangan Achievement Emotion Terhadap Achievement Goal Siswa Di Sman 1. Jurnal Psikologi Pendidikan Dan Perkembangan, 6(2), 72-88. Http://Journal.Unair.Ac.Id/Download-FullpapersJpppddfff20ebafull.Pdf 
2190 Pengaruh Konseptual Achievement Emotion dan Lingkungan Belajar Peserta Didik terhadap Achievement Goal - Harry Theozard Fikri, Billy Hendrik, Mardhiah Masril

DOI: https://doi.org/10.31004/edukatif.v3i4.1155

Daryanti, M. S. (2018). Hubungan Lingkungan Belajar Dengan Prestasi Belajar Mahasiswa. Jurnal Kebidanan Dan Keperawatan Aisyiyah, 12(1), 84-89. Https://Doi.Org/10.31101/Jkk.129

Dluha, M. S., \& Solicha, S. (2019). Pengaruh Perfeksionisme, Achievement Goal Orientation Dan Jenis Kelamin Terhadap Prokrastinasi Akademik Mahasiswa. TAZKIYA: Journal Of Psychology, 6(1), 53-68. Https://Doi.Org/10.15408/Tazkiya.V6i1.11003

Fadilah, R. W. Z., Maslihah, S., \& Misbach, I. H. (2018). Pengaruh Academic Emotions Dan School Belonging Terhadap Students' Life Satisfaction Pada Siswa Menengah Pertama. Jurnal Psikologi Insight, 2(1), 90-99. Https://Doi.Org/10.17509/Insight.V2i1.11948

Hadi, I., \& Netrawati. (2021). Contribution Of Emotional Intelligence And Parental Social Support In Student Learning Achievement. ... Journal Of Applied Counseling And Social ..., 2(1), 55-66. Http://Bk.Ppj.Unp.Ac.Id/Index.Php/Ijacss/Article/View/399

Kartika, W. I. (2021). PENDIDIKAN Hubungan Antara Lingkungan Keluarga Dan Hasil Belajar IPS Siswa Di Sekolah Dasar. Edukatif: Jurnal Ilmu Pendidikan, 3(4), 1318-1325.

Kohoulat, N., Dehghani, M. R., Kojuri, J., \& Hayat, A. A. (2016). Achievement Goals And Achievement Emotions In Elementary School Students. International Journal Of School Health, 3(2), 1-7. Https://Doi.Org/10.17795/Intjsh-32193

Kusumastuti, D., \& Mastuti, E. (2018). Perbedaan Self-Regulated Learning Ditinjau Dari Valensi Achievement Emotions Pada Mahasiswa Yang Sedang Mengerjakan Skripsi. Jurnal Psikologi Pendidikan Dan Perkembangan, 7(1), 46-58.

Muna, K. (2017). Pengaruh Tujuan Berprestasi Terhadap Keterampilan Metakognisi Siswa Dalam Pemecahan Masalah Kimia (Studi Korelasional Pada Siswa XI IPA SMAN 2 Banjarmasin. 8(1), 89-98.

Nurcahyanti, A., \& Setyawan, I. (2014). Hubungan Antara Iklim Sekolah Dengan Orientasi Tujuan Performa Pada Siswa Sekolah Menengah Pertama. Empati: Jurnal Karya Ilmiah S1 Undip, 3(4), 62-73.

Pekrun, R. (2014). Emotions And Learning. In S. Vosniadou (Ed.), Religious Education (Pp. 1-32). Educational Practices Series National And Kapodistrian University Of Athens. Https://Doi.Org/10.1080/00344087.2019.1669866

Pratama, H. J., \& Ghofur, M. A. (2021). Pengaruh Motivasi Belajar Dan Lingkungan Belajar Terhadap Hasil Belajar Mata Pelajaran Ekonomi Siswa Saat Pembelajaran Daring. Edukatif: Jurnal Ilmu Pendidikan, 3(4), 1568-1577. Https://Edukatif.Org/Index.Php/Edukatif/Article/View/621

Putra, A. S., \& Soetikno, N. (2018). Pengaruh Intervensi Psikoedukasi Untuk Meningkatkan Achievement Goal Pada Kelompok Siswi Underachiever. Jurnal Muara Ilmu Sosial, Humaniora, Dan Seni, 2(1), 254 261. Https://Doi.Org/10.24912/Jmishumsen.V2i1.1514

Putri, R. Y., \& Supriansyah. (2021). Pengaruh Literasi Digital Terhadap Kesiapan Kerja Generasi Z Di Sekolah Menengah Kejuruan. Edukatif: Jurnal Ilmu Pendidikan, 3(5), 3007-3017. Https://Doi.Org/Https://Doi.Org/10.31004/Edukatif.V3i5.1055 Copyright

Saraswati, P. (2019). Kemampuan Self Regulated Learning Ditinjau Dari Achievement Goal Dan Kepribadian Pada Remaja. Indigenous: Jurnal Ilmiah Psikologi, 4(2), 69-78. Https://Doi.Org/10.23917/Indigenous.V4i2.7209

Wahyudi, I., Yusuf, A. M., \& Afdal. (2021). Analisis Terhadap Holland Theory Dan Implikasinya Dalam Bimbingan Karir Pada Siswa. 3(5), 1880-1890.

Wardani, D. N., Toenlioe, A. J. E., \& Wedi, A. (2018). Daya Tarik Pembelajaran Di Era 21 Dengan Blended Learning. Jurnal Kajian Teknologi Pendidikan (JKTP), $1(1), \quad 13-18$ Https://Core.Ac.Uk/Download/Pdf/287323676.Pdf

Widyaningtyas, A., Karmin, \& Radiyono, Y. (2013). Peran Lingkungan Belajar Dan Kesiapan Belajar Terhadap Prestasi Belajar Fisika Siswa Kelas X Sekolah Menengah Atas Negeri 1 Pati. Jurnal Pendidikan Fisika, 1(1), 136-143. 
2191 Pengaruh Konseptual Achievement Emotion dan Lingkungan Belajar Peserta Didik terhadap Achievement Goal - Harry Theozard Fikri, Billy Hendrik, Mardhiah Masril

DOI: https://doi.org/10.31004/edukatif.v3i4.1155 